特集論支「エージェント」

\title{
マルチエージェント交通流シミュレーションにお ける交通事故モデリング
}

\section{Modeling of Traffic Accident in Multi-agent-based Traffic Simulator}

\author{
$\underset{\text { Hideki Fujii }}{\text { 藤樹 }}$ \\ 東京大学大学院工学系研究科 \\ School of Engineering, Univ. of Tokyo \\ fujiiesys.t.u-tokyo.ac.jp \\ 吉村 忍
Shinobu Yoshimura \\ (同上) \\ yoshiesys.t.u-tokyo.ac.jp, http://save.sys.t.u-tokyo.ac.jp/ \\ 高野 悠哉 \\ (同上) $* 1$
}

keywords: traffic simulation, traffic accident, driver model, recognition error model, field of view

\section{Summary}

Road traffic is a key portion of infrastructure to support mobility and transportation of human beings and goods. At the same time, it includes various kinds of risks. One of the most critical ones is a traffic accident. To evaluate traffic accidents quantitatively, we have newly developed a cognitive error model and implemented it into a multi-agent based traffic simulator. In the traffic simulator, each component creating traffic phenomena is modeled as an agent, and interaction among numerous agents simulates nonlinear behaviors of urban traffics. An actual traffic accident often occurs when a car driver overlooks something to watch, such as other cars, pedestrians, traffic signals, or obstacles. In the cognitive error model we developed, a driver agent has its own field of view and a gazing point, and cannot recognize objects off the gazing point. Through various types of test simulations using the developed simulator, we demonstrate that the simulator with the cognitive error model is a powerful tool to quantitatively evaluate traffic accidents and to discover such a dangerous situation that accidents frequently occur.

\section{1. 緒言}

\section{1·1 ITS と交通事故}

近年 ITS (高度道路交通システム, Intelligent Transport Systems) 技術の発展はめざましく，樣々なシステムが実 用化されてきた . 実用化された代表的な技術が VICS (道 路交通情報通信システム) やETC (ノンストップ自動料 金支払いシステム) である．一方，これらと比べて「安全 運転の支援」に関しては実用化がなかなか進んでいない． 車車間通信技術など交通事故低減の技術は一部の高級車 に採用されているが本格的実用化には程遠い状況にある． これは前二者に対し導入効果が見えにくいこと，システ 么導入のコストが多大となることが原因である．

とはいえ，交通事故予防に関して ITS への期待は大き い. 近年では車両性能や医療技術の進歩により事故発生 件数, 死者数ともに減少しているが，光れでも年間 5000 名以上が交通事故により命を落としており，また高齢者 か関与する交通事故が社会問題となりつつある [警察 09]

$* 1$ 現在は株式会社野村総合研究所に勤務
ITS を用いた事故予防には機器が情報提供し運転手が 危険を認識する「注意喚起」と機器が危険を察知し自動 ブレーキをかける「介入制御」の 2 種類がある . しかしど ちらも実環境での実証テストは多くの困難を伴い，事故 削減効果の定量的な評価は難しいというのか現状である .

\section{$1 \cdot 2$ 交通事故の原因と運転挙動}

自動車を運転するという行為は, 以下に示す認知・判 断・操作の 3 つのフェーズに分類して考えることができ る [ITARDA 03, ITARDA 05] .

認知フェーズ

周囲の交通状況を視覚等によって確認し, 安全に運 転する上で把握しておくべき対象を認識する . 把握 すべき対象としては前方を走行中の車両や信号機な どが挙げられる .

判断フェーズ

認知した情報から対象の挙動を予測し，自身の次の 行動を決定する．見えない危険を積極的に避けよう 
表 1 認知エラー

\begin{tabular}{|l|l|}
\hline 認知エラー & $\begin{array}{l}\text { 物陰になっていて他車が見えない } \\
\text { 脇見をしていて信号を見ていない } \\
\text { 交通量が少ないので確認を怠った }\end{array}$ \\
\hline 判断エラー & $\begin{array}{l}\text { 先行車が予想外に停止した } \\
\text { 相手が道を讓ってくれると思った } \\
\text { 自動車が出てくることはないと思った }\end{array}$ \\
\hline 操作エラー & $\begin{array}{l}\text { ハンドル操作を誤った } \\
\text { ブレーキとアクセルを踏み間違えた }\end{array}$ \\
\hline
\end{tabular}

とする, いわゆる防衛運転もこの判断の範疇に含ま れる .

操作フェーズ

判断に従ってアクセル・ブレーキを踏んだり，ハン ドル操作によって進行方向を変えたりする．

認知した情報から判断を行い，判断に従って操作し，操 作によって変化した周囲の状況を再ひ認知する，という ように, 運転中はこのサイクルが常に繰り返されている． この 3 段階の運転挙動のどれか, あるいは複数が適切に 実施されなかった場合に交通事故が発生する可能性が生 じる．交通事故総合分析センター (ITARDA) 等はこれ をエラーと呼んでおり，上記 3 フェーズに合わせて光れ 光れ認知エラー, 判断エラー，操作エラーが定義されて いる．表 1 に光れぞれのエラーの具体例を示す．

交通事故を類型別に分析すると，追突事故が $31 \%$, 出 会い頭事故が $26 \%$ と，この 2 種類で交通事故全体の半数 以上を占めており [ITARDA 05], さらに追突事故の当事 者のうち 77\%[ITARDA 03], 出会い頭事故の当事者のう ち 79\%[ITARDA 05] が認知エラーを起こしていること が分かっている．乥こで本研究では, まず認知エラーを 対象として詳細に分析することとする .

\section{$1 \cdot 3$ 本研究の目的}

実環境におけるテストの代替，あるいはテストの前段 階として , シミュレーションによって ITS の交通事故予 防効果を予測することを考える．弚のためには図 1 に示 すような交通流シミュレーションを含めた統合的なシミュ レーションシステムが必要となる .これを ITS 統合シミュ レーションと呼ぶこととする .

人間の肉体だけでは認知できないような情報をシステ ムが提供することで事故の低減を図るのが安全運転支援 システムの目的である . 従って , ITS 統合シミュレーショ ンの交通流モジュールではドライバーが非現実的な認知 機構を持っていてはならない．しかし，筆者らか現在開 発している知的マルチェージェント交通流シミュレータ MATES [吉村 04, Yoshimura 06, 藤井 06, 吉村 09] を含 む多くのマルチェージェントベースの交通流シミュレー タでは, 車両は周囲に存在する全ての他車両の正確な位 置座標や速度を瞬時に取得することが可能であり，ITS

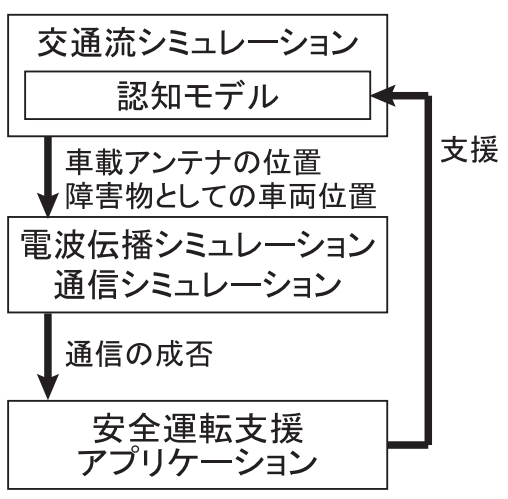

図 1 ITS 統合シミュレーションの概略

統合シミュレーションとしての要求を満たさない．

本研究は ITS 統合シミュレーションの実現を最終目標 とし，光の第一段階として交通流シミュレータ内のエー ジェントに認知モデルを実装し，認知エラーに起因する 交通事故発生機構を構築することを目的とした . 弚のた めにドライバーの視野と視点移動をモデル化し，建物や 車両の死角によって事故か溌生する状況のシミュレーショ ンを行った・またモデルの特性を感度解析によって確認 し，応用例として高齢ドライバーの運転時のリスクにつ いて検討した 。

\section{4 関 連 研 究}

マルチェージェントタイプの交通流シミュレータの中 で認知に関わるパラメータを持つモデルとして , 定数と して visible distance を定め情報取得を制限するモデル [Barceló 02]や，相手車両に関する誤った情報を確率的に 与えるモデル [Paruchuri 02] 等が考案されているが，ど ちらのモデルもエラーが発生したという結果をエージェ ントに与えるものである .

安全運転支援システムとは事故が発生するミクロなプ ロセスに働きかけるものであり，目視によって認知でき ない対象物を通信によって認知できるようになることで 事故の発生を抑制する . 通信の結果は自車両と認知対象 となる車両，遮蔽物としての建造物や他の車両の位置関 係に応じて物理計算によって一意に定められる．交通流 シミュレータにおいても状況に応じた目視による認知の 成否を明示的に取り扱う必要があるが，全ての状況を場 合分けしてェラー率のようなマクロな情報を与えるのは 現実的ではなく，本論文で述べるような視野を考慮した ドライバーモデルを採用する必要がある .

\section{2. シミュレーション手法}

$2 \cdot 1$ マルチェージェント 型交通流シミュレータ

本研究で利用する交通流シミュレータは MATES のコ ンセプトに従って作成されたテストシミュレータであり， マルチェージェント手法を用いたシミュレータである . ド 


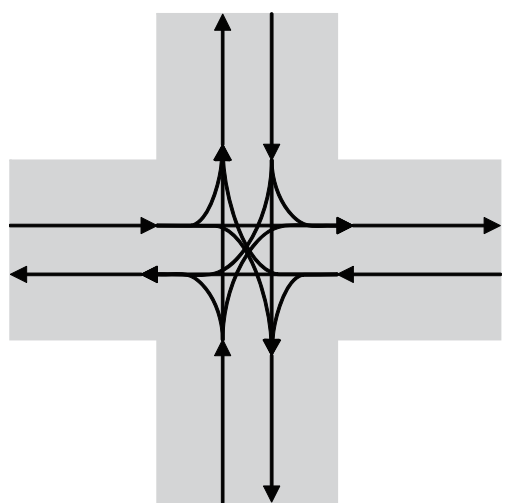

図 2 交差点付近の仮想走行レーン

ライバーェージェントは後述する視覚認知モデルによっ て他車両を認知し, 認知された車両に対してのみ車両位 置や速度といった情報を取得，エージェントが危険と判 断した場合には減速する．逆に言えば，認知できる車を 視覚認知モデルで制限することによって認知エラーが発 生し, 弚れか泇減速判断・操作に影響を及ぼすことで事 故が発生する.

\section{$\S 1$ 道路環境}

本研究用に開発したテストシミュレータにおける道路 ネットワークは，車線を模した仮想走行レーンを最小単 位とする有向グラフとして表現される (図 2).

車両の進行方向は仮想走行レーンによって制御される ため，交差点内部にもレーンが作成される．また車両進 行方向は視線の方向に大きく関与するため，交差点進入 時に進行方向が大きく変わることのないよう, 右左折用 レーンは曲線で表される .

車両位置は所属する仮想走行レーンと谷のレーンの始 点からの距離によって表される . 本研究では操舵は考慮 しない。

\section{$\S 2$ 車両エージェントの挙動}

道路を走行中の車両の自律的な挙動決定を微視的自律 性と呼んでいる．一方で巨視的自律性とは経路選択を指 し，MATES では大域的な道路ネットワークにおいて，走 行距離, 予想旅行時間, 道路の直進および右左折回数, 道路幅を考慮した効用関数を最大とするような経路探索 機能を持つ．ただし本研究では簡略化のため前方交差点 での進行方向を確率的に決定するにとどめた．車両エー ジェントの微視的自律性として次のものを考慮した .

\section{交通ルールの遵守}

車両は道路環境から提供される信号情報や制限速度 等の規制情報を自身て解釈し，仮想走行レーン上を 走行する.

\section{加速度の決定}

Generalized Force Model (GFM)[Helbing 98] を応用 して車両の加速度を決定する．GFM は先行車の影 響を仮想的な斥力として車両に与えるモデルであり，
弚の概念は次式で表される .

$$
\frac{d v_{i}(t)}{d t}=f_{i}^{0}\left(v_{i}(t)\right)+\sum_{j \neq i} f_{i j}(t)+\xi_{i}(t)
$$

ここで, $v_{i}(t)$ は時刻 $t$ における車両 $i$ の速度で あり, $f_{i}^{0}\left(v_{i}(t)\right)$ は車両 $i$ の希望速度までの加速力, $f_{i j}(t)$ は車両 $i$ が車両 $j$ から受ける斥力, $\xi_{i}(t)$ は摇 らぎおよび弚の他の影響を表す項である．本研究で は $\xi_{i}(t) を 0$ として扱う.

GFM は先行車の情報のみにもとづく加速度決定 モデルであるが, 一方, 現実の都市交通では信号や 前方交差点で交錯する恐れのある車両等, 加速度決 定要因は多岐にわたる，光こで本シミュレータでは 道路状況を反映する仮想先行車を導入することによ り，あらゆる要因に対して GFM を適用できるよう に拡張した。

GFM を用いて求められる加速度の絶対值が大きす ぎる場合には光れを補正する. 本研究では, 最大加 速度は $2.0 \mathrm{~m} / \mathrm{s}^{2}$ とし, 事故に大きく関わる急ブレー キ時の最大減速度は 2008 年度自動車アセスメント [国土 08] を参考に $8.0 \mathrm{~m} / \mathrm{s}^{2}$ と定めた . 加速度が決 定された後, 乥れに従って速度と車両位置が更新さ れる .

\section{走行車線の選択}

前述の通り，本シミュレータでは走行中の車両が次の 交差点でどちらの方向に進むかは確率的に与えられ る.与えられた進行方向を達成するために道路区間 内での仮想走行レーンを適切に選択する . このレー ン選択には単純な線形探索を用いる。

\section{$2 \cdot 2$ 視野と認知エラーのモデル化}

\section{$\S 1$ 画像処理による視覚認知のモデル化}

運転時に得られる情報のうち $90 \%$ が視覚情報であると される [Hartman 70] .ゆえに視覚認知によって車両挙動 がどのように変化するのかを考慮することが重要である．

本研究では, 運転席から見える風景を計算機上で再現 し，弚の視覚情報から状況判断を行うモデルを新たに提 案する．ドライバーの視界を考慮した交通流シミュレー タとして，2 次元平面上で幾何学的な演算によって可視 判定を行うモデルが提案されているが (例えば [久保田 06]），弚れと比へて画像処理によって認知するモデルを 用いることで道路勾配や車高等 3 次元的な影響を考慮す ることが可能となり，より一般的な状況での視覚認知モ デルが構築できる．画像処理による視覚認知モデルのイ メージを图 3 に示す．

運転席から見える風景をタイムステップごとにディス プレイに描画し，画像内の1ピクセルごとの RGB 值を 抽出する . 抽出された情報の中に車両を表す色があるか ないかて認知を行う．車両と同色の背景でなければ色情 報のみで他車両を確認することができる．自分の視野内 


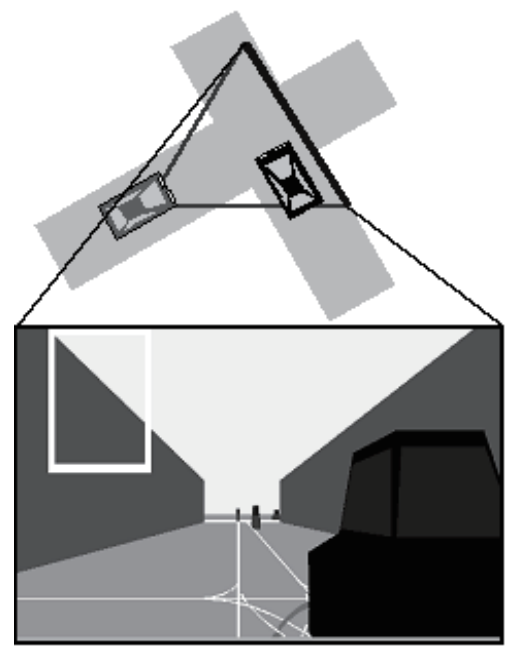

図 3 画像処理を利用した視覚認知モデル (上図左側の車両から見 える風景を下図で示す .)

に他車両が存在すると分かれば，弚の情報をもとにして 前述の加速度制御を行う。

$\S 2$ 中心視野と周辺視野の導入

人間は図 3 で示されるような視界全体から情報を取得 できるわけではなく，注視点と呼ばれる極めて小さな領 域から取得した情報のみを繋ぎ合わせて脳内に映像を作っ ている . 注視点をシミュレータ上でモデル化することに より，脇見運転や見落とし等「見えているはずなのに見 ていない」認知エラーによる事故を再現することができ るようになる。

人間の視野のうち，注視点を中心とする解像度の高い 領域は中心視野と呼ばれ，乥れ以外の領域は周辺視野と 呼ばれる. 中心視野か対象物の認知に大きな役割を果た し，周辺視野は視界全域の中から特徵的な物を抽出する 機能を持つ [澤 02].

速度が上がれば上がるほど周辺視野は狭まる，停止時 の周辺視野角は 200 度であるが , $40 \mathrm{~km} / \mathrm{h}$ で走行時には 100 度， $100 \mathrm{~km} / \mathrm{h}$ で走行時には周辺視野角は 40 度にま で狭まる.本研究においては高速道路ではなく一般道を $40 \mathrm{~km} / \mathrm{h}$ で走行することを想定し，周辺視野角は 100 度 で固定した . 本来, 停止時の視野角は 200 度であり，速 度上昇に伴い周辺視野の角度は減少するが, 速度と周辺 視野角の詳細な関係については研究が進んでいないこと や，個人差も大きい部分でもあるため，本シミュレータ においては一律で視野角 100 度を採用した。

シミュレータ内でのドライバーの中心視野と周辺視野 は图 4 のように再現される .

$\S 3$ 注視点の移動と対象物の認知

人間は周辺視野によって特徵物を抽出した後，眼球運 動によって注視点を移動させ，特徵的な対象物を中心視 野内におさめる．対象物を中心視野で捉え一定時間が経 過してはじめて弚の物か識別され認知される .

本研究で作成した認知モデルでは，まず周辺視野内で

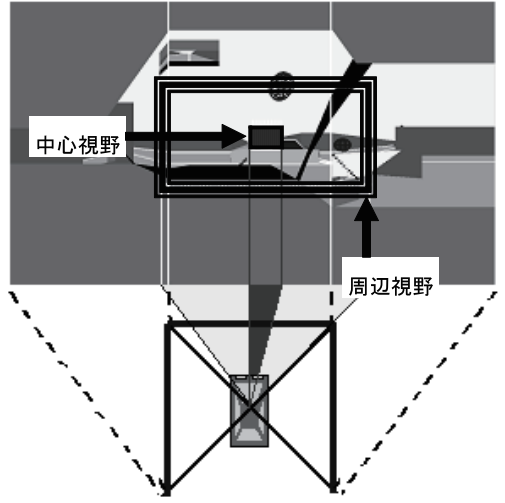

図 4 ドライバーの周辺視野と中心視野

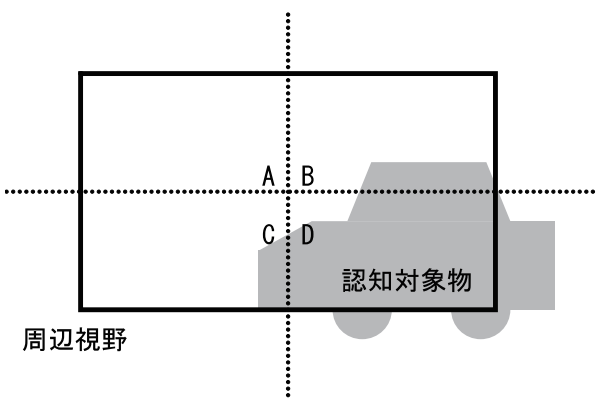

図 5 周辺視野領域の分割

最も大きな面積を占める対象物 (自動車・信号等) にむ けて注視点を移動する．㫕のためにまず周辺視野を図 5 のように 4 分割し，各領域に描画される対象物のピクセ ル数から次のタイムステップにおける注視点の移動方向 を定める.すなわち图 5 の領域 A，B，C，D に含まれ る対象物のピクセル数を兴れ光れ $a, b, c, d$ とした場合 に， $(a+b)-(c+d)$ の值が正であれば上，負であれば 下と移動方向を定める . 同樣に $(a+c)-(b+d)$ の值が 正であれば左 , 負であれば右とする .

注視点の移動の後, 対象物を中心視野内で一定時間 (以 下，認知完了時間と呼ぶ）捉えることで認知を完了する ものとする . また ，ドライバーは他車を認知した瞬間だ けでなく, 認知後もしばらくは光の挙動を予測して運転 するものと考えられる . シミュレータでは認知後一定時 間 (以下, 認知切れ時間と呼ぶ) が経過するまて認知状 態を継続し，中心視野の外にあっても対象の情報を入手 できるよう定めた .

運転中の視点移動は受動的視点移動と能動的視点移動 の 2 つに分類される . 周辺視野で対象物を発見し，注視 点を移動させる行為は受動的視点移動にあたり，光の速 度は 1 秒あたりおよ光 15 度とされる [小高 00] . 周辺視 野内に注視すべき対象物が存在しない場合には能動的視 点移動となり，我々のモデルでは $80 \%$ の確率で画面中央 に，10\%でルームミラーに，各 5\%で左右のサイドミラー に注視点を移動させる．受動的視点移動と違い視点移動 の前にあらかじめ見るべき対象物を意識しているため， 


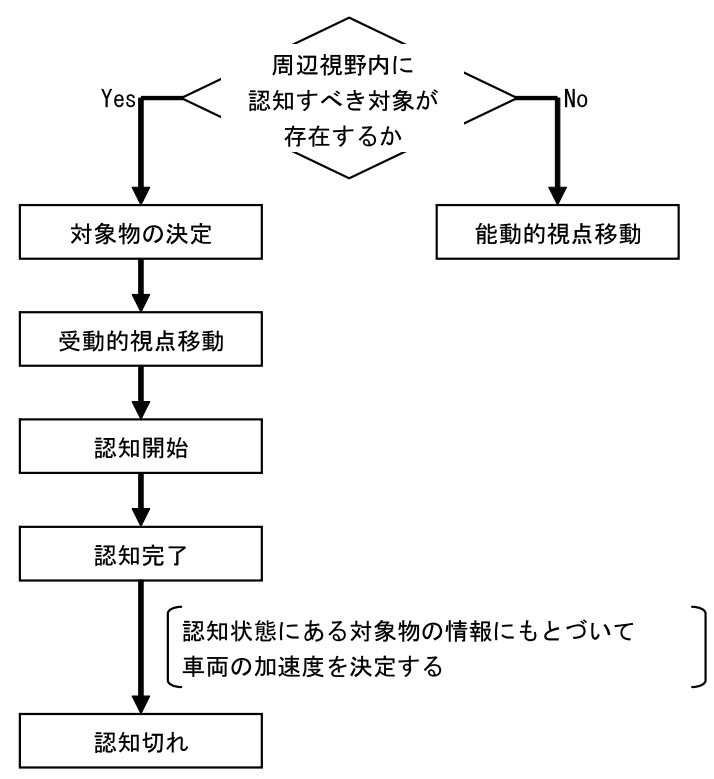

図 6 提案した認知モデルのフロー

能動的視点移動の速度は受動的視点移動の速度より速く， 1 秒あたりおよ光 180 度とされる．なお能動的視点移動 の移動先を与える確率は本来個人の特性, 運転の習熟度 や道路状況などによって変化するものであるが，本研究 では一律の確率を与えた。

作成した認知モデルのフローを图 6 に示す .

\section{3. 交通事故発生のシミュレーション}

構築したシミュレータを使って, 視野内に認知すべき車 が大量に存在し，死角から現れた車を見落とすことで㣫 突事故が発生する樣子をシミュレータ上で再現する . シ ミュレーション中のスクリーンショットを図 7 に示す.実 際にはシミュレータは各タイムステップの静止画を出力 し，光れらを辌ぎ合わせた動画として交通状況を確認す ることができる .

图 7 は交差点を右折しようとする車両の運転席から見 える風景の動画の一部であり，まさに交差点に進入しよ うとする時刻のスナップショットである．画面左側に描画 されているのは対向方向から交差点に進入し，右折を終 えた車両である．ドライバーの注視点はこの右折車両を 追い続けてしまい，右折車両の死角から現れた後続の直 進車両 (画面中央の車両) に注意が向いていない.シミュ レーションではこの後実際に衝突事故が発生することを 確認している. 図 8 に図 7 で描かれた車両の位置関係を 示す . 図 7 は車両 A からの視点であるが , シミュレータ の中では同時に車両 C のドライバーからも車両 A が見 えていない状況が生まれていることを確認しており，双 方の認知エラーが事故に結びついている .

現実の道路交通においても，車両の死角から現れた別 車両の認知が遅れてしまったために発生する衝突事故は

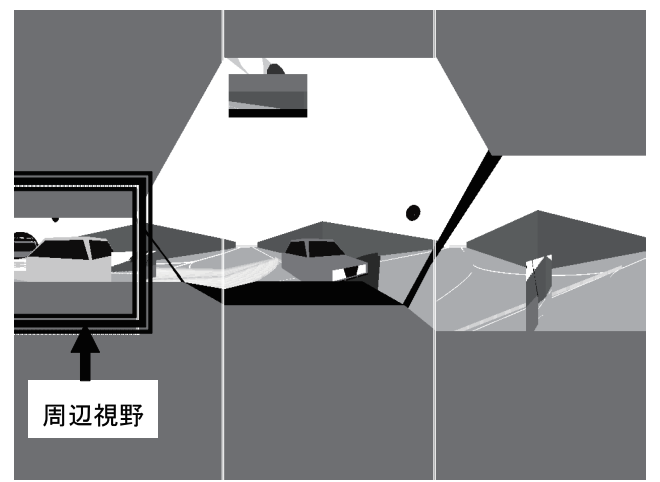

図 7 注意分散による事故発生の樣子 (注視点は左の車両を追って いて正面の車両に気づいていない .)

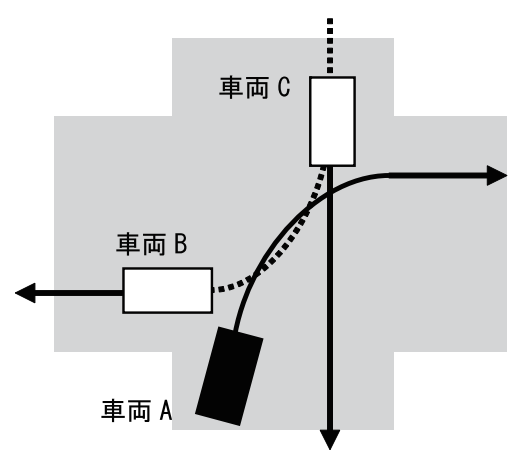

図 8 図 7 中の車両の位置関係 (図 7 は車両 $\mathrm{A}$ から見た風景であ り，注視点が右折済みの車両 $\mathrm{B}$ を追ってしまったために後続 の直進車両 $\mathrm{C}$ を見落としてしまった状況を示している.)

多い. しかし大半のマルチェージェント型交通流シミュ レータでは死角に入っている車両の情報まで完全に把握 して車両の挙動決定を行うため, 現実の交通と比較して 安全寄りの状況が再現され，ここで示すような衝突事故 は発生しない . 本論文て提案する認知モデルをシミュレー タに導入することにより，環境の急激な変化にドライバー が対応できなかったり，あるいは注意の分散によって重要 な情報を見落としたりする事象の発生を確認できた .こ れらは現実の事故発生原因としても十分考えられる .こ の先, 安全運転支援システムの注意喚起 ・ 介入制御機能 によって上記の事象の発生件数を低減できるということ が示されれば，ITS 統合シミュレーションによって交通 事故予防効果を評価できることとなる .

\section{4. 感 度 解 析}

本研究で構築した認知モデルにはいくつかの生理学的 パラメータが使われているが，ある種の幅を持っている． 乥こで, 弚のパラメータ変化がシミュレータ内で再現さ れる交通システム全体の挙動にどのように影響するか分 析する. 
表 2 認知モデルで用いるパラメータの標準值

\begin{tabular}{|l|r|}
\hline 中心視野の大きさ & 10 度 \\
\hline 周辺視野の大きさ & 100 度 \\
\hline 受動的視点移動速度 & 15 度 $/ \mathrm{sec}$ \\
\hline 認知完了時間 & $0.4 \mathrm{sec}$ \\
\hline 認知切れ時間 & $5.0 \mathrm{sec}$ \\
\hline
\end{tabular}

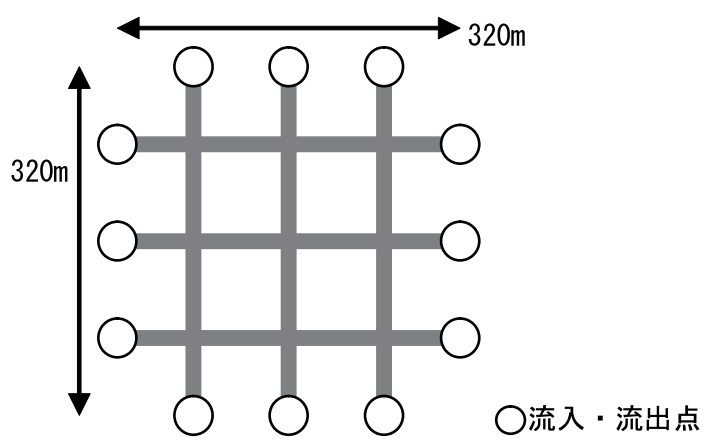

図 9 感度解析に用いた道路ネットワーク

\section{$4 \cdot 1$ 認知モデルに関するパラメータ}

認知モデルに用いるパラメータと产の標準值を表 2 に 示す. 前述した周辺視野・中心視野の大きさ [澤 02] と視 点移動速度 [小高 00] は, 運転挙動の分析で用いられる 一般的な值である．以下ではこれらの值の変化が結果に 及ぼす影響について調査する。

\section{$4 \cdot 2$ シミュレーション条件}

表 2 に掲げたパラメータのうち，ひとつを標準值の $1 / 8$ ， $1 / 4,1 / 2,2,4,8$ 倍と变化させ, 他を標準值に固定した ままシミュレーションを行い, 各ドライバーか認知する 車両の総数を測定する.

解析には図 9 で示した道路ネットワークを用いる。光 れ光れのネットワーク端点および交差点を接続する道路 区間の長さは全て $80 \mathrm{~m}$ であり, 各交差点には信号か設置 されていない，道路以外は全て視界を遮る壁とした。

車の流入点をランダムに選択しながら 2 秒に 1 台の割 合で車を発生させ，車両総数が 20 台になった時点で測定 を開始する．なお，交差点での進行方向を確率的に与え るため，測定中にネットワーク端点から車両が流出する ことがある．弚の場合には流出した分を追加し走行車両 が常に 20 台である状態を保つ．

シミュレーション時間で 20 分間の計測を行い, 全ドラ イバーが認知した他車両の台数の総和を求めた。なお計 算に用いた時間刻み幅は 0.1 秒である。

\section{$4 \cdot 3$ 解 析 結 果}

図 10 は視点移動速度と認知台数の関係を示したもので ある. 4 pixel/step $(=15$ 度/sec) をピークに減少してい る.これは 1 ステップでの視点移動幅が大きすぎると対 象物を飛び越し，認知できなくなることが原因であると

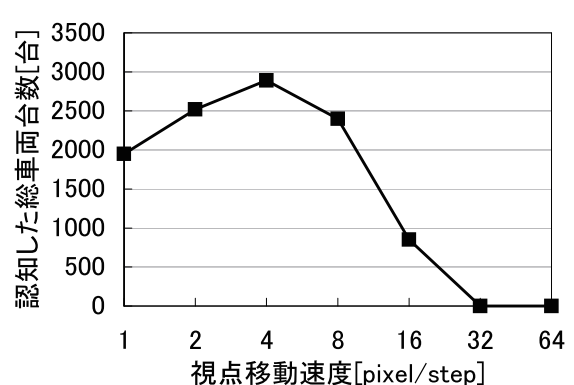

図 10 視点移動速度と認知台数との関係

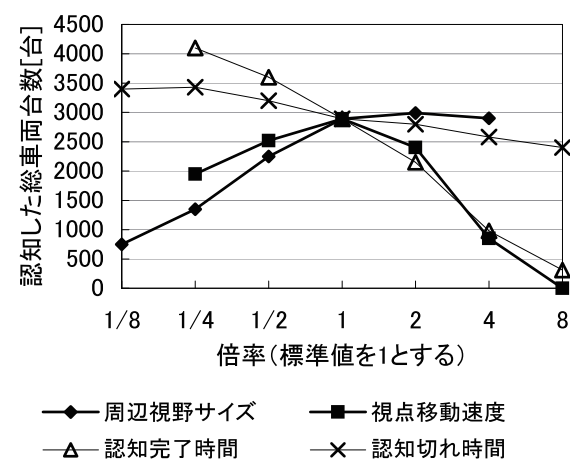

図 11 認知パラメータと認知台数の関係

考えられる．高速な視点移動を実装するためにはより小 さな時刻刻み幅を設定する必要がある．しかし標準值と

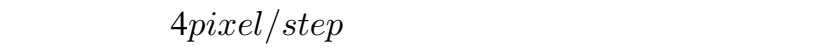
本シミュレーションにおける時間刻み幅が適切であった といえる .

同樣に表 2 の各パラメータを変化させた場合の倍率と 認知台数をパラメータごとに示したものが図 11 である. 視点移動速度と認知完了時間は標準值の 4 倍以上になる と多くの車を認知できなくなることが分かる．周辺視野 の大きさはある閾值を超えると認知台数に影響を与えな いが, 人間の取り得る視界の大きさ以下では認知台数に 大きく関与する .

\section{5. 応用例：高齢者ドライバーのリスク評価}

\section{$5 \cdot 1$ 高齢者の事故と視野}

我が国では近年，社会全体の高齢化に伴い高齢運転者 による交通事故件数か増加しつつある. 本研究で作成し たシミュレータの応用例として，高齢者の生理的特性を 考慮し，弚れらが交通事故にどのようにつながるかを評 価する。

高齢者の視野範囲は若年者と比較して著しく低下する ことが知られており [金光 03]，視野狭窄によって運転時 に注意すべき対象物に目が向かない等，樣々な悪影響を 及ぼすと考えられる．高齢者ドライバーの視野狭窄によ る認知特性の違いに関する研究 [森田 05] はあるが, 乥 


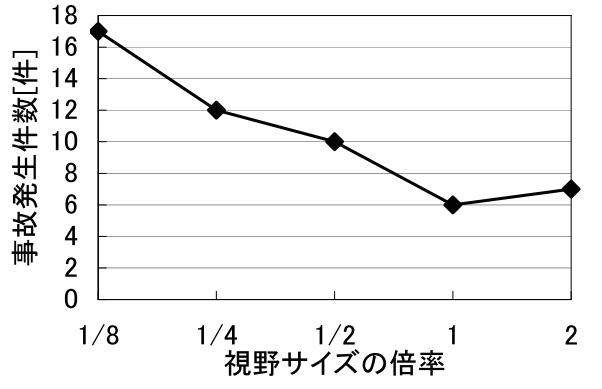

図 12 周辺視野の大きさと事故発生件数

れか結果的に交通事故発生率に及ぼす影響の大きさは分 からない，光こで，本シミュレータを用いて視野狭窄の 程度と光れに伴うリスクについて評価を行うこととする．

\section{$5 \cdot 2$ シミュレーション条件}

图 9 と同じ道路ネットワークを用い，周辺視野の大き さを変化させた時に事故の発生件数がどの程度増加する かを評価する.車同士の距離が $0.5 \mathrm{~m}$ 以下になった場合を 衝突発生とみなし，40 分間での事故発生件数を測定した .

\section{$5 \cdot 3$ 結 果}

図 12 に周辺視野の倍率と事故発生件数の関係を示す. 事故発生数の絶対值は今後モデルの精緻化で現実に近い 值が得られるであろうが，視野が狭くなるほど事故の割合 か増加するという定性的な傾向を確認することができる．

图 13 にはシミュレーション中の若年ドライバーと高齢 ドライバーの周辺視野を示す . 全ての車両の位置は同一 であるが , 若年ドライバーの周辺視野には 3 台の車両が 含まれているのに対し，高齢ドライバーの周辺視野には 1 台の車両しか含まれておらず，必然的に認知すべき対 象物の見落としが発生しやすくなる .

\section{6. 結言}

本研究ではドライバーの中心視野・周辺視野・注視点 の移動に基づく認知モデルを構築し，マルチェージェン 卜型交通流シミュレータに導入して認知エラーによる交 通事故の発生を確認した .

また本研究では, 認知モデルに含まれる生理学的パラ メータに関する感度解析を実施し，モデルの特性を示し た . 本研究は新たな認知エラーモデルのプロトタイピン グであり，定量的な妥当性を評価する段階にない，現実 の事故率を再現するためのパラメータの設定あるいは光 の取得方法については今後議論する必要があるが，ITS 統合シミュレーションにとっては光れ以上に現実の人間 の認知機能がどれだけ交通流シミュレーションモデルに 組み込まれているかが重要である．見えないものを認知 しないという必須条件は本研究のモデルにおいて十分に 達成された . また定性的ではあるものの，視野の広さ，視

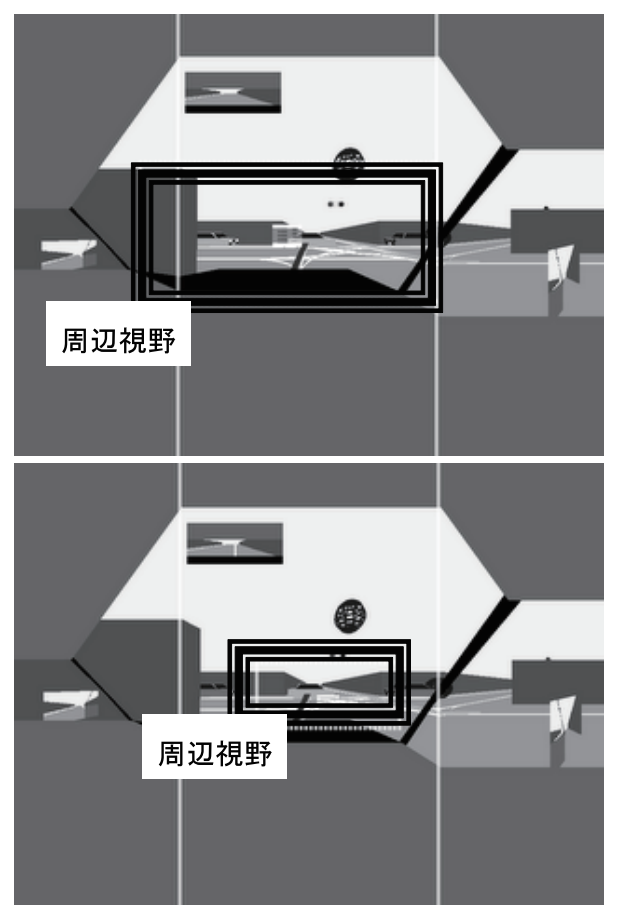

図 13 若年者 (上) と高齢者 (下) の周辺視野 (高齢者の視野を 若年者の $1 / 4$ と設定したケース .)

点移動速度等のパラメータの差異が認知エラー, 交通事 故の発生件数の増減にどのように関与しているか示した こと，乥れらが直感的に解釈可能な結果であったことは 上記の観点から意義があったと言える . 加えて , シミュ レーションの応用事例として高齢者の視野狭窄の運転に 与える影響を評価した．本研究で採用した研究アプロー チは , シミュレーションによる ITS の導入効果の測定は もとより，夜間や霧中走行時のリスク評価にも応用可能 であると考える

1.2 で述べた 3 つのフェーズのうち, 認知以外の各プ ロセスについての考慮は今後の課題である . 本研究の認 知モデルでは, 情報を得られなかった対象物は存在して いないのと同義であり，車両の加速度決定に何ら影響を 及ぼさない．しかし実際のドライバーは突然の状況変化 に備え，対象物の存在を認知する前にあらかじめ危険を 回避するような運転を行う. 実現象の再現性を向上させ るためには, 認知モデルだけでなく判断モデルについて も高度化する必要がある. 判断モデルには, 認知モデル 以上に心理学的な影響あるいは個人の特性が反映される と考えており，これらをどのようにドライバーモデルに 組み込むかが重要となる. 本研究で提案した認知モデル のパラメータを適切に設定し，判断モデルを高度化する ことで, ITS 統合シミュレーション中の交通流モジュー ルとしての要求を満たすことができるであろうと考える .

また, 計算時間も課題として残る.今回の研究ではシ ミュレータに登場する全ての車両について画像を作成す るため, 5 分間のシミュレーションを実施するために車 両 1 台あたり約 2 分を要する. 大規模シミュレーション 
を実施するためには 1 台あたりの処理時間を改善するか， あるいは計算機の並列化，視野計算の外部化について考 えねばならない . ITS 統合シミュレーションにおいて電 波伝播・通信シミュレーションとを連携させる場合には， 共通点の多い視野計算と電波伝播シミュレーションとを 外部プログラムとしてまとめ, 計算を効率化することを 検討している。

\section{$\diamond$ 参 考 文 献 $\diamond$}

[Barceló 02] Barceló, J. and Casas, J.: Dynamic Network Simulation with AIMSUN, in International Symposium Proceedings on Transport Simulation (2002)

[藤井 06] 藤井 秀樹, 仲間 豊, 吉村忍 : 知的マルチェージェント交 通流シミュレータ MATES の開発（第二報：歩行者エージェン 卜の実装と歩車相互作用の理論・実測値との比較）, シミュレー ション, Vol. 25, No. 4, pp. 274-280 (2006)

[Hartman 70] Hartman, E.: Driver vision requirements, Society of Automotive Engineers, pp. 629-630 (1970)

[Helbing 98] Helbing, D. and Tilch, B.: Generalized Force Model of Traffic Dynamics, Physical Review E, Vol. 58, pp. 133-138(1998)

[ITARDA 03] ITARDA (財) 交通事故総合分析センター:ITARDA Information (2003)

[ITARDA 05] ITARDA (財) 交通事故総合分析センター:ITARDA Information (2005)

[金光 03] 金光 義弘 : 高齢運転者における視野異常の実態 : 視野 の経年変化に関する調査的研究を通して, 川崎医療福祉学会誌, Vol. 13, No. 2, pp. 257-262 (2003)

[警察 09] 警察庁 : 平成 20 年中の交通事故の発生状況 (2009)

[小高 00] 小高 泰, 末広 和代, 三浦 健一郎, 河野 憲二 : 円滑追跡 眼球運動と追従眼球運動の相互作用, 電子技術総合研究所彙報, Vol. 63, No. 12 (2000)

[国土 08] 国土交通省 : 自動車アセスメントーブレーキ性能試験 の試験結果 (2008)

[久保田 06] 久保田 大介, 西本 知弘, 松下浩明: 交通事故の危険 度を予測するための交通シミュレータの開発, 情報処理学会研究 報告. ITS, [高度交通システム], No. 22, pp. 23-30 (2006)

[Paruchuri 02] Paruchuri, P., , Pullalarevu, A., and Karlapalem, K.: Multi agent simulation of unorganized traffic, in Proceedings of the first international joint conference on Autonomous agents and multiagent systems, pp. 176-183(2002)

[澤 02] 澤 喜司郎：交通安全概論説, 成山堂書店, 改訂 2 版 (2002)

[吉村 04] 吉村忍, 西川紘史, 守安 智 : 知的マルチェージェント 交通流シミュレータ MATES の開発, シミュレーション, Vol. 23, No. 4, pp. 228-237 (2004)

[Yoshimura 06] Yoshimura, S.: MATES: Multi-Agent Based Traffic and Environment Simulator - Theory, Implementation and Practical Application, Computer Modeling in Engineering and Sciences, Vol. 11, No. 1, pp. 17-25 (2006)

[吉村 09] 吉村忍, 関計哉, 藤井 秀樹 : 高速道路合流部の知的マ ルチェージェントシミュレーション, 交通工学, Vol. 44, No. 1, pp. 81-90 (2009)

[森田 05] 森田 和元, 関根 道昭, 岡田竹雄, 益子仁一, 大野督史 : 高 齢運転者の認知・操作特性に関する実験的検討, 交通安全環境研 究所研究発表会講演概要, pp. 93-98 (2005)

〔担当委員：松原 繁夫〕

2009 年 12 月 18 日 受理

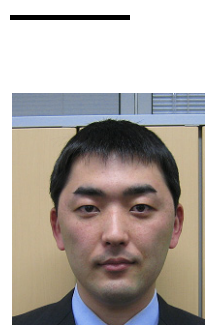

者 紹 介

藤井 秀樹 (正会員)

2003 年東京大学工学部システム創成学科卒業 . 2009 年同 大学大学院新領域創成科学研究科人間環境学専攻博士後期 課程修了. 同年, 同大学人工物工学研究センター価值創成 イニシアティブ (住友商事) 寄付研究部門特任助教.2010 年より同大学大学院工学系研究科システム創成学専攻助教。 博士 (環境学) . 交通流シミュレーションに関する研究に 従事。日本機械学会, 日本シミュレーション学会, 交通工 学研究会各会員

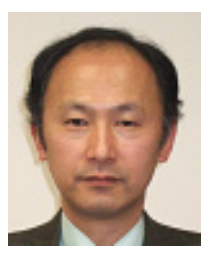

吉村 忍

1981 年東京大学工学部原子力工学科卒業. 1987 年同大学 院博士課程修了. 工博. 同大学院工学系研究科システム量 子工学専攻助教授, 新領域創成科学研究科環境学専攻教授 等を経て,2008 年より工学系研究科システム創成学専攻 教授 . 知的シミュレーションの研究開発と工学分野, 社会. 環境分野への応用に関する研究・教育に従事. 日本計算力 学連合副会長, 日本機械学会フェロー。

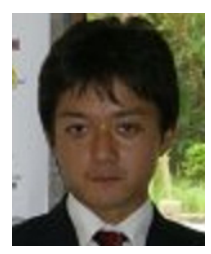

\section{高野 悠哉}

2007 年東京大学工学部システム創成学科卒業. 2009 年同 大学大学院工学系研究科システム量子工学専攻修了. 同年, 株式会社野村総合研究所入社.現在に至る。在学中は交通 流シミュレーションに関する研究に従事。 